\title{
Effect of adipose tissue-derived inflammatory and proangiogenic cytokines on proliferative diabetic retinopathy
}

\author{
[Adipoz doku kaynaklı inflamatuvar ve proanjiyojenik \\ sitokinlerin proliferatif diyabetik retinopati üzerine etkisi]
}

\author{
Demet Aban Yabanoğlu', \\ Çağman Sun Tan ${ }^{2}$, \\ Sibel Kadayıfçılar ${ }^{1}$, \\ Bora Eldem ${ }^{1}$, \\ Sevilay Karahan ${ }^{3}$
}

\begin{abstract}
${ }^{1}$ Department of Ophthalmology, Hacettepe University Faculty of Medicine, Ankara; ${ }^{2}$ Department of Pediatrics, Immunology Unit, Hacettepe University Faculty of Medicine, Ankara; ${ }^{3}$ Department of Biostatistics, Hacettepe University
\end{abstract} Faculty of Medicine, Ankara

Correspondence Address

[Yazışma Adresi]

Demet Aban Yabanoğlu, M.D.

316. Cadde, 338. Sokak, No: 1/5, Kırkkonaklar, 06610 Ankara, Türkiye

Phone: +90 3124954903

E-mail: demetaban@gmail.com

\begin{abstract}
Objective: To determine the vitreous and serum concentrations of TNF- $\alpha$, IL-6, VEGF, IL-1 $\beta$, IL-8, IL-17, MCP-1, IL-1Ra, IL-10 in patients with proliferative diabetic retinopathy (PDR) and to investigate the effect of adipose tissue on the pathogenesis of PDR.

Methods: Twenty-two patients with PDR were prospectively evaluated. Seven cadavers and 11 patients with idiopathic epiretinal membrane or macular hole served as the controls. Multiplex bead array technology was employed to assess the concentrations of the cytokines.

Results: The intravitreal levels of VEGF, IL-8, IL-6 were significantly higher in PDR group than control groups. In PDR group, the levels of IL-17, IL-8, IL-6 were significantly elevated in the vitreous, whereas the intravitreal levels of IL-10, IL-1Ra were found to be significantly lower than the serum concentrations. No significant correlation was found between cytokine levels and body mass index (BMI), fasting blood glucose (FBG), or glycated haemoglobin (HbA1c) of diabetic patients.

Conclusion: In PDR the balance between the intravitreal pro- and anti- inflammatory adipocytokines is disturbed in favor of proinflammatory and proangiogenic cytokines in the vitreous humour. This study supports the role of adipocytokines in vascular pathology in PDR. It seems that PDR is a local inflammatory disease. However, obesity may not be the root of the inflammatory mediators in PDR.
\end{abstract}

Key Words: Multiplex bead analysis, adipose tissue, adipocytokines, obesity, proliferative diabetic retinopathy, inflammation

Conflict of Interest: The authors declare no conflict of interest.

\section{ÖZET}

Amaç: Proliferatif diyabetik retinopati'de (PDR) serum ve vitreus TNF- $\alpha$, IL-6, VEGF, IL-1 $\beta$, IL-8, IL-17, MCP-1, IL-1Ra, IL-10 konsantrasyonlarını saptamak ve adipoz doku kaynaklı inflamatuvar sitokinlerin PDR patogenezindeki etkisini araştırmaktır.

Metod: Yirmi iki PDR hastası prospektif olarak değerlendirildi. Kontrol grubu olarak 7 kadavra ile 11 idiyopatik epiretinal membran veya maküler delik olgusu değerlendirildi. Adipositokin konsantrasyonlarını değerlendirmede çoklu boncuk analizi yöntemi kullanıldı.

Bulgular: Vitreus VEGF, IL-6 ve IL-8 konsantrasyonları PDR grubunda kontrol gruplarına göre anlamlı olarak yüksek saptand1. PDR grubunda vitreus IL-17, IL-6 ve IL-8 konsantrasyonları serum değerlerinden anlamlı olarak yüksek saptanırken, vitreus IL-10 ve IL-1Ra değerleri serum değerlerinden anlamlı olarak düşük bulunmuştur şeklinde olacaktır. Diyabetik hastalarda vücut kütle indeksi, açlık kan glukozu ve glikozile hemoglobin ile adipositokin konsantrasyonları arasında istatistiksel olarak anlamlı bir korelasyon saptanmamıştır.

Sonuç: PDR'de vitreus pro- ve anti- inflamatuvar adipositokinler arasındaki denge proinflamatuvar ve proanjiyojenik sitokinler lehine bozulmuştur. Çalışmamız PDR'deki damarsal patolojide adipositokinlerin rolünü desteklemektedir. Öyle görünüyor ki PDR lokalize bir inflamatuvar hastalıktır. Bununla birlikte obezite PDR'de inflamatuvar moleküllerin asıl kaynağı olmayabilir. Anahtar Kelimeler: Çoklu boncuk analizi, adipoz doku, adipositokinler, obezite, proliferatif diyabetik retinopati, inflamasyon

Çıkar Çatışması: Yazarların çıkar çatışması yoktur. 


\section{Introduction}

Obesity is a major health problem all over the world that is responsible for noninsulin-dependent (type 2) diabetes mellitus (DM) and its serious complications, such as retinopathy, nephropathy, cardiovascular disease. In diabetic eyes, neovascularization results in blindness through vitreous hemorrhage, retinal detachment, or glaucoma. Retinal hypoxia is the crucial factor for these sight-threatening complications [1]. However, in PDR the mechanism of retinal hypoxia remains poorly understood. Chronic subclinical inflammation is one of the underlying cause of the vascular pathologies in PDR $[2,3]$. Vascular changes, enhanced vascular permeability, endothelial cell damage and capillary nonperfusion are triggered by retinal leukocyte stasis and inflammatory and proangiogenic factors in the vitreous fluid $[4,5]$.

Recent studies show that there is an enhanced secretion of hormones, growth factors and inflammatory cytokines in adipose tissue of the obese, which is called adipocytokines [6]. Adipocytokines are involved in the regulation of energy balance, lipid and glucose metabolism, angiogenesis, blood pressure, tumor growth, and metastasis [7-12]. The concentration in blood of many adipocytokines are altered in obesity [6]. Obesity and inflammation is a crucial step contributing to the emergence of insulin resistance, type 2 $\mathrm{DM}$ and its vascular complications [13].

Our hypothesis is that the inflammatory and proangiogenic cytokines that are abundantly released from adipose tissue (TNF- $\alpha$, IL-6, VEGF, IL-1 $\beta$, IL-8, IL-17, MCP-1, IL-1Ra, IL-10) have a key role in PDR. Another hypothesis is that abdominal adipose tissue is the main source of these molecules. If our hypotheses are correct we would predict that some of the circulating and/or intravitreal inflammatory and proangiogenic adipocytokine levels would increase and there will be a significant positive correlation between the circulating and/or intravitreal concentration of these molecules and the metabolic parameters (BMI, FBG, $\mathrm{HbA1c}$ ) in diabetic patients. The purpose of the present investigation was to test this prediction by employing the multiplex cytokine array system.

\section{Methods}

\section{Subjects}

Twenty-two patients with type $2 \mathrm{DM}$ who underwent pars plana vitrectomy (PPV) for vitreous hemorrhage were included in this study. We excluded patients with a history of previous vitreoretinal surgery, intravitreal therapy, vitreous hemorrhage in the last two months, photocoagulation in the last 3 months. Control groups composed of two groups as follows; the control group 1, comprised of 11 patients who underwent PPV for idiopathic macular hole or idiopathic epiretinal membrane; the control group 2 embodied seven cadavers. Exclusion criteria for the control groups was presence of ocular pathology, DM history, systemic malignancy, and sepsis.
This study was approved by the Ethics Committee for Clinical Studies of Hacettepe University, Faculty of Medicine. We obtained informed consent for blood sampling from each patient.

In the ophthalmic examination we assessed the best corrected visual acuity, slit lamp examination, indirect ophthalmoscopy and ocular ultrasonography. During the preoperative physical examination we noted body weight and height of each patient, then calculated BMI $(\mathrm{kg} /$ $\mathrm{m}^{2}$ ), and we obtained blood samples for FBG $(\mathrm{mg} / \mathrm{dL}$ ) and $\mathrm{HbAlc}(\mathrm{mmol} / \mathrm{mol})$. We referred all patients to the endocrinology department prior to surgery. Insulin doses were changed for eight patients who had a FBG of $\geq 200$ $\mathrm{mg} / \mathrm{dL}$ (Table 1).

\section{Sample collection}

Vitreous fluid: In the study group and the control group 1 , we collected minimum $0.5 \mathrm{~mL}$ undiluted vitreous fluid specimens at the beginning of PPV prior to the opening of the infusion port. In the control group 2, we obtained vitreous samples from the cadavers within six hours after death. Physiological saline solution was injected for cosmetic restoration of eyeball after aspiration of vitreous fluid. The specimens were collected into sterile plastic tubes and immediately transferred to the laboratory on ice. Samples were centrifuged at $5000 \mathrm{~g}$ for 10 minutes, and stored at $-80^{\circ} \mathrm{C}$ until assayed.

Serum: We obtained serum samples from the study group and the control group 1 during PPV from the venous circulation at the antecubital fossa. The samples were immediately transferred to the laboratory on ice. Samples were centrifuged at $4000 \mathrm{~g}$ for 10 minutes, and stored at $-20^{\circ}$ $\mathrm{C}$ until assayed.

\section{Multiplex bead immunoassay}

We determined concentrations of cytokines in both vitreous and serum samples using Luminex $200^{\mathrm{TM}}$ instrument. Multiplex bead kits were purchased from Invitrogen Inc. Camarillo, CA, USA (Invitrogen Human Cytokine 30-Plexi ${ }^{\circledR}$ Panel; catalog number LHC6003) [14]. The assay was performed according to the manufacturer's instructions with Luminex laser based fluorescent analytical test instrumentation [14]. The concentrations of the samples were determined from the standard curve using curve fitting software (Master Plex ${ }^{\circledR}$ Reader Fit). Standard curves for each cytokine were generated by using the reference cytokine concentrations supplied by the manufacturer [14].

During analyzing the samples the vacuum manifold could not aspirate the serum samples of five diabetic patients (case 11, 15, 16, 19, 22) and two control group 1 patients during the washing stages mainly due to the clogging of the filter plate. Thus, we excluded these specimens from the study. 
Table 1. Clinical and biochemical characteristics of the study group

\begin{tabular}{|c|c|c|c|c|c|c|c|c|c|c|c|c|c|}
\hline \multirow[t]{2}{*}{ Case } & \multirow{2}{*}{$\begin{array}{c}\text { Age } \\
\text { (years) }\end{array}$} & \multirow[t]{2}{*}{ Sex } & \multirow[t]{2}{*}{ Laterality } & \multirow{2}{*}{$\begin{array}{l}\text { Visual } \\
\text { acuity }\end{array}$} & \multirow{2}{*}{$\begin{array}{l}\text { PRP } \\
\text { history }\end{array}$} & \multicolumn{4}{|c|}{ Systemic diseases } & \multirow{2}{*}{$\begin{array}{l}\text { Medical } \\
\text { treatment }\end{array}$} & \multirow{2}{*}{$\begin{array}{c}\text { BMI } \\
\left(\mathrm{kg} / \mathrm{m}^{2}\right)\end{array}$} & \multirow{2}{*}{$\begin{array}{c}\text { FBG } \\
(\mathrm{mg} / \mathrm{dL})\end{array}$} & \multirow{2}{*}{$\begin{array}{c}\mathrm{HbA} 1 \mathrm{c} \\
(\mathrm{mmol} / \mathrm{mol})\end{array}$} \\
\hline & & & & & & HT & $\mathrm{HL}$ & $\mathrm{CHD}$ & RPD & & & & \\
\hline 1 & 53 & $\mathrm{~F}$ & OD & CF at $3 \mathrm{~m}$ & + & + & - & - & - & OHT+insulin & 35 & 298 & 76 \\
\hline 2 & 56 & $M$ & OS & CF at $1 \mathrm{~m}$ & + & + & - & + & + & Insulin & 32 & 221 & 81 \\
\hline 3 & 57 & $\mathrm{M}$ & OD & $20 / 100$ & - & + & - & - & + & OHT+insulin & 25 & 170 & 65 \\
\hline 4 & 68 & $\mathrm{~F}$ & OS & CF at $2 \mathrm{~m}$ & + & + & - & - & - & Insulin & 22 & 133 & 71 \\
\hline 5 & 65 & $\mathrm{~F}$ & OD & HM & - & + & - & - & + & OHT+insulin & 40 & 114 & 38 \\
\hline 6 & 65 & $M$ & OS & LP & + & + & - & - & - & Insulin & 31 & 94 & 65 \\
\hline 7 & 39 & $\mathrm{M}$ & OS & $20 / 16$ & + & + & - & - & + & Insulin & 26 & 135 & 76 \\
\hline 8 & 66 & $F$ & OS & $\mathrm{HM}$ & + & - & - & - & - & OHT+insulin & 35 & 188 & 59 \\
\hline 9 & 66 & $\mathrm{~F}$ & OS & HM & + & - & - & - & - & OHT+insulin & 34 & 321 & 110 \\
\hline 10 & 61 & $\mathrm{~F}$ & OS & CF at $1 \mathrm{~m}$ & + & + & - & + & + & Insulin & 23 & 116 & 49 \\
\hline 11 & 55 & $M$ & OD & $\mathrm{HM}$ & + & + & - & - & - & Insulin & 36 & 105 & 119 \\
\hline 12 & 53 & $F$ & OS & $20 / 400$ & + & + & - & - & - & OHT+insulin & 26 & 177 & 77 \\
\hline 13 & 44 & $M$ & OS & CF at $1 \mathrm{~m}$ & + & - & - & - & - & Insulin & 30 & 90 & 90 \\
\hline 14 & 72 & $\mathrm{~F}$ & OD & $\mathrm{HM}$ & + & + & + & - & - & Insulin & 32 & 200 & 86 \\
\hline 15 & 45 & $F$ & OD & $\mathrm{HM}$ & + & - & - & - & - & OHT+insulin & 18 & 287 & 71 \\
\hline 16 & 67 & $M$ & OD & $\mathrm{CF}$ at $2 \mathrm{~m}$ & + & + & + & - & - & Insulin & 27 & 234 & 66 \\
\hline 17 & 55 & $F$ & OD & $\mathrm{HM}$ & + & - & - & - & + & Insulin & 38 & 140 & 50 \\
\hline 18 & 63 & $\mathrm{~F}$ & OS & $20 / 400$ & - & + & + & + & - & Insulin & 31 & 130 & 58 \\
\hline 19 & 58 & $M$ & OS & $\mathrm{HM}$ & + & + & - & + & - & OHT+insulin & 27 & 70 & 75 \\
\hline 20 & 55 & $M$ & OS & $\mathrm{HM}$ & + & + & - & - & + & OHT+insulin & 29 & 300 & 102 \\
\hline 21 & 77 & $F$ & OD & CF at $2 \mathrm{~m}$ & - & + & - & - & - & Insulin & 34 & 208 & 75 \\
\hline 22 & 56 & $\mathrm{~F}$ & OD & $20 / 100$ & + & + & + & + & - & Insulin & 38 & 200 & 70 \\
\hline
\end{tabular}

F: Female; M: Male; OD: Right eye; OS: Left eye; CF: Counting fingers; HM: Hand motion; LP: Light perception; PRP: Panretinal photocoagulation; HT: Hypertension; HL: Hyperlipidemia; CHD: Coronary heart disease; RPD: Renal parenchymal disease; OHT: Oral hypoglycemic treatment; BMI: Body mass index; FBG: Fasting blood glucose; HbA1c: Glycated haemoglobin.

In this study we compared serum and vitreous cytokine levels among the three groups. We also compared vitreous, and serum cytokine concentrations of diabetic patients. In diabetic patients we analyzed the correlation between the circulating and intravitreal cytokine levels with FBG, HbA1c, and BMI.

\section{Statistical analysis}

Statistical Analysis was performed with Statistical Package for Social Sciences software of Windows, version 15 (SPSS Inc., Chicago). Chi-square, and Kruskal-Wallis tests were used to compare age, sex, laterality ratios, and systemic diseases between the study group, and the control groups. The Mann-Whitney U test was applied to compare the concentrations of cytokines of serum samples between the study group, and the control group 1. The Kruskal-Wallis test was used to compare concentrations of cytokines of vitreous fluid specimens between three groups. Wilcoxon signed rank test was employed to compare the difference between the intravitreal, and serum cytokine levels in the study group. In the study group partial correlation coefficient was performed to evaluate the association between the cytokine concen- trations and the metabolic parameters $(\mathrm{FBG}, \mathrm{HbA} 1 \mathrm{c}$, and BMI). A 2-tailed $p$ value of $<0.05$ was considered significant.

\section{Results}

Study group comprised of 13 females and nine males with a mean age of $58 \pm 10.5$ years. Three (13.6\%) patients had documented epiretinal membrane, and three (13.6\%) patients had documented tractional retinal detachment at the time of PPV. The clinical and biochemical characteristics of the study group are presented in Table 1. Study group had a mean BMI of $31 \pm 6 \mathrm{~kg} / \mathrm{m}^{2}, \mathrm{FBG}$ of $179 \pm 74 \mathrm{mg} / \mathrm{dL}$, and $\mathrm{HbAlc}$ of $74 \mathrm{mmol} / \mathrm{mol}$.

The control group 1 composed of nine females and two males with a mean age of $62.7 \pm 7.8$ years. Five $(45.5 \%)$ patients had idiopathic macular hole and six (54.5\%) idiopathic epiretinal membrane. The best corrected visual acuity was $\geq 20 / 200$ in nine $(81.8 \%)$ patients and $<20 / 200$ in two $(18.2 \%)$ patients. Six $(54.5 \%)$ patients had hypertension, two $(18.2 \%)$ patients had hyperlipidemia, and one $(9.1 \%)$ patient had coronary artery disease. The cont-rol group 2 embodied three females, and four males 
Table 2. Vitreous and serum concentrations of adipocytokines in the groups

\begin{tabular}{|c|c|c|c|c|c|c|}
\hline $\begin{array}{l}\text { Adipocytokines } \\
(\mathrm{pg} / \mathrm{mL})\end{array}$ & & $\begin{array}{c}\text { Control } \\
\text { group } 1 \\
\text { serum }(n=9)\end{array}$ & $\begin{array}{l}\text { Study group } \\
\text { serum }(n=17)\end{array}$ & $\begin{array}{c}\text { Study group } \\
\text { vitreous }(n=22)\end{array}$ & $\begin{array}{c}\text { Control } \\
\text { group } 1 \\
\text { vitreous }(n=10)\end{array}$ & $\begin{array}{c}\text { Control } \\
\text { group } 2 \\
\text { vitreous }(n=10)\end{array}$ \\
\hline \multirow[t]{3}{*}{ VEGF } & $\mathrm{M} \pm \mathrm{SD}$ & $8.5 \pm 2.5$ & $8.7 \pm 1.6$ & $10.05 \pm 3.1$ & $6.6 \pm 0.7$ & $5.9 \pm 1.1$ \\
\hline & Mdn & 8.5 & 8.9 & 8.7 & 6.6 & 6.2 \\
\hline & Range & $(4-11.5)$ & $(4.5-11)$ & (6.2-17.05) & $(5.7-8)$ & $(4-7.1)$ \\
\hline \multirow[t]{3}{*}{ TNF-a } & $\mathrm{M} \pm \mathrm{SD}$ & $39.7 \pm 5.2$ & $37 \pm 7.9$ & $39.1 \pm 4$ & $36.5 \pm 5.2$ & $36.9 \pm 5.5$ \\
\hline & Mdn & 39.8 & 38.1 & 39 & 37.3 & 38.1 \\
\hline & Range & (32.9-48.6) & $(24.5-50)$ & $(31-50)$ & $(26.8-42.9)$ & $(25.7-42.1)$ \\
\hline \multirow[t]{3}{*}{ IL-6 } & $\mathrm{M} \pm \mathrm{SD}$ & $45.5 \pm 37.4$ & $51.5 \pm 55.3$ & $85 \pm 80.9$ & $31.9 \pm 11.4$ & $42.4 \pm 27.2$ \\
\hline & Mdn & 33.7 & 35 & 64.1 & 27.7 & 29.6 \\
\hline & Range & $(22.4-143.5)$ & $(16.2-234.6)$ & $(25-394.5)$ & $(22.4-59.7)$ & $(24.9-95)$ \\
\hline \multirow[t]{3}{*}{ IL-1 $\beta$} & $\mathrm{M} \pm \mathrm{SD}$ & $59.6 \pm 16.9$ & $58.5 \pm 14.8$ & $61.6 \pm 5.3$ & $60.8 \pm 5.7$ & $60.7 \pm 8.7$ \\
\hline & Mdn & 53.4 & 55.4 & 62.8 & 61 & 61 \\
\hline & Range & (35.4-96.8) & (35.4-88.6) & $(51.3-72.4)$ & $(51.3-69.3)$ & $(46.8-75.3)$ \\
\hline \multirow[t]{3}{*}{ IL-8 } & $\mathrm{M} \pm \mathrm{SD}$ & $174.2 \pm 106$ & $144.7 \pm 47.8$ & $239.2 \pm 199$ & $113 \pm 37.5$ & $113.4 \pm 35.6$ \\
\hline & Mdn & 123.7 & 127.2 & 180 & 99.65 & 101.8 \\
\hline & Range & $(105-382)$ & $(104.4-305.6)$ & (101.3-1010) & $(87.4-213.2)$ & (84.9-186.7) \\
\hline \multirow[t]{3}{*}{ IL-17 } & $\mathrm{M} \pm \mathrm{SD}$ & $47.3 \pm 13.3$ & $54.3 \pm 22.6$ & $102.5 \pm 12.5$ & $99 \pm 17.8$ & $89.5 \pm 16.4$ \\
\hline & Mdn & 47 & 55 & 104 & 101 & 91 \\
\hline & Range & $(33.3-74)$ & $(14.8-100.3)$ & $(72.2-124.9)$ & $(74-132)$ & (59-107) \\
\hline \multirow[t]{3}{*}{ IL-10 } & $\mathrm{M} \pm \mathrm{SD}$ & $239 \pm 50.7$ & $243.2 \pm 98.6$ & $184.1 \pm 7.64$ & $181.3 \pm 3.21$ & $189.9 \pm 14.1$ \\
\hline & Mdn & 236.9 & 205.3 & 184.2 & 182.7 & 189.6 \\
\hline & Range & $(194.2-361.7)$ & $(189.6-537.6)$ & $(177.8-211.4)$ & $(177.8-184.2)$ & (169.4-208.5) \\
\hline \multirow[t]{3}{*}{ MCP-1 } & $\mathrm{M} \pm \mathrm{SD}$ & $742.5 \pm 189.6$ & $746.7 \pm 267.8$ & $892.5 \pm 473.5$ & $560 \pm 204.1$ & $519 \pm 170.3$ \\
\hline & Mdn & 699.4 & 671.2 & 736.8 & 453.1 & 433.8 \\
\hline & Range & $(521.3-1121)$ & (488.8-1619.9) & (313.7-2036.9) & (338.5-887.7) & $(378.9-850.7)$ \\
\hline \multirow[t]{3}{*}{ IL-1Ra } & $\mathrm{M} \pm \mathrm{SD}$ & $676.4 \pm 319.5$ & $859.6 \pm 747.4$ & $288 \pm 138.3$ & $330.7 \pm 298.1$ & $248 \pm 256.4$ \\
\hline & Mdn & 569.3 & 640.8 & 236 & 209.9 & 124 \\
\hline & Range & $(252.4-1281)$ & $(272.3-3407.3)$ & $(124-669.6)$ & $(124-1113.6)$ & $(69.5-800.6)$ \\
\hline
\end{tabular}

$\mathrm{M} \pm \mathrm{SD}:$ Mean \pm standart deviation; Mdn: Median.

with a mean age of $64.4 \pm 14$ years. Four (57.1\%) had hypertension and five $(71.4 \%)$ had coronary heart disaese.

There was no statistical difference between three groups in terms of age, sex, ratio of patients with hypertension, coronary heart disease, and hyperlipidemia. The ratio of patients with renal parenchymal disease were significantly higher in the diabetic group $(\mathrm{p}=0.03)$.

The cytokine concentrations of groups are presented in Table 2. The median values of the intravitreal VEGF were significantly higher in the study group than control groups
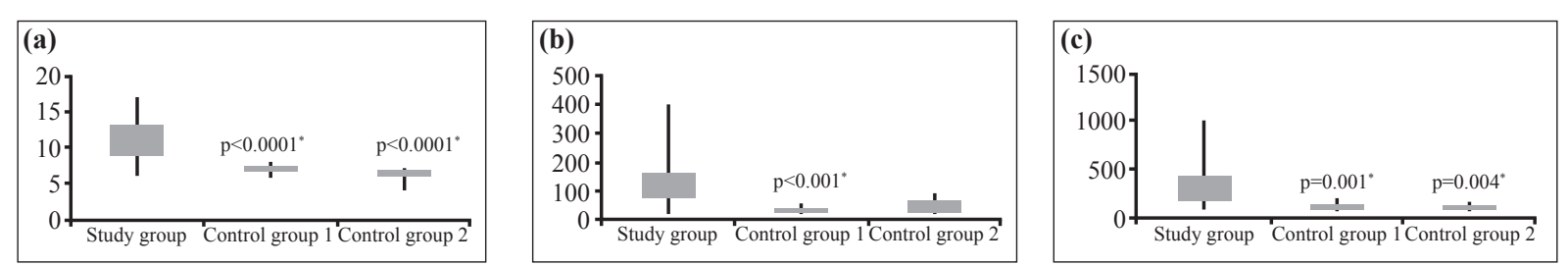

Figure 1. Distribution of the intravitreal adipocytokines within the groups. (a) The median levels of VEGF; study group: $8.7 \mathrm{pg} / \mathrm{mL}, \mathrm{con}-$ trol group 1: $6.6 \mathrm{pg} / \mathrm{mL}$, control group 2:6.2 pg/mL. (b) The median IL-6 concentrations; study group $64.1 \mathrm{pg} / \mathrm{mL}$, control group 1: 27.7 $\mathrm{pg} / \mathrm{mL}$, control group 2: $42.4 \mathrm{pg} / \mathrm{mL}$. The median values of the intravitreal IL-6 were significantly higher in the study group compared to the control group 1. (c) The median levels of IL-8; study group:180 pg/mL, control group 1: $99.65 \mathrm{pg} / \mathrm{mL}$, control group 2: $101.8 \mathrm{pg} / \mathrm{mL}$. The median values of the intravitreal VEGF and IL- 8 were significantly rise in the study group compared to control groups both. ${ }^{*} \mathrm{p}<0.017$, Bonferroni correction. 
Table 3. Correlation analysis of adipocytokines with BMI, FBG, and $\mathrm{HbA1c}$

\begin{tabular}{|c|c|c|c|c|c|c|c|}
\hline \multirow[t]{2}{*}{ Adipocytokines (pg/mL) } & & \multicolumn{2}{|c|}{ BMI $\left(\mathrm{kg} / \mathrm{m}^{2}\right)$} & \multicolumn{2}{|c|}{$\mathrm{FBG}(\mathrm{mg} / \mathrm{dL})$} & \multicolumn{2}{|c|}{$\mathrm{HbA} 1 \mathrm{c}(\mathrm{mmol} / \mathrm{mol})$} \\
\hline & & $r$ & $\mathrm{p}$ & $r$ & $\mathrm{p}$ & $r$ & $\mathrm{p}$ \\
\hline \multirow[t]{2}{*}{ VEGF } & Serum & 0.286 & 0.322 & 0.276 & 0.34 & -0.061 & 0.835 \\
\hline & Vitreous & -0.198 & 0.415 & 0.3 & 0.212 & -0.32 & 0.182 \\
\hline \multirow[t]{2}{*}{ TNF-a } & Serum & 0.043 & 0.883 & 0.159 & 0.587 & 0.382 & 0.177 \\
\hline & Vitreous & 0.133 & 0.586 & 0.19 & 0.435 & -0.006 & 0.982 \\
\hline \multirow[t]{2}{*}{ IL-6 } & Serum & -0.062 & 0.834 & 0.197 & 0.5 & 0.197 & 0.499 \\
\hline & Vitreous & -0.096 & 0.696 & 0.45 & 0.053 & -0.124 & 0.613 \\
\hline \multirow[t]{2}{*}{ IL-1 $\beta$} & Serum & 0.317 & 0.27 & 0.001 & 0.998 & 0.041 & 0.89 \\
\hline & Vitreous & 0.258 & 0.286 & 0.192 & 0.43 & -0.151 & 0.536 \\
\hline \multirow[t]{2}{*}{ IL-8 } & Serum & 0.061 & 0.837 & -0.08 & 0.785 & -0.235 & 0.418 \\
\hline & Vitreous & -0.112 & 0.649 & 0.241 & 0.321 & -0.375 & 0.113 \\
\hline \multirow[t]{2}{*}{ IL-17 } & Serum & 0.058 & 0.845 & 0.088 & 0.765 & -0.014 & 0.962 \\
\hline & Vitreous & -0.258 & 0.386 & -0.113 & 0.646 & -0.098 & 0.691 \\
\hline \multirow[t]{2}{*}{ IL-10 } & Serum & -0.095 & 0.748 & 0.202 & 0.489 & 0.233 & 0.422 \\
\hline & Vitreous & -0.012 & 0.962 & 0.278 & 0.248 & -0.255 & 0.293 \\
\hline \multirow[t]{2}{*}{ MCP-1 } & Serum & 0.157 & 0.591 & 0.025 & 0.933 & -0.271 & 0.348 \\
\hline & Vitreous & -0.256 & 0.29 & 0.083 & 0.736 & -0.238 & 0.326 \\
\hline \multirow[t]{2}{*}{ IL-1Ra } & Serum & -0.025 & 0.932 & 0.062 & 0.833 & -0.353 & 0.216 \\
\hline & Vitreous & -0.14 & 0.586 & 0.084 & 0.733 & -0.17 & 0.488 \\
\hline
\end{tabular}

Note: Partial correlation coefficient was performed to evaluate the association between the cytokine concentrations and the metabolic parameters (FBG, HbA1C, and BMI). The effect of age, sex, and systemic diseases ( hypertension, coronary heart disease, hyperlipidemia, renal parenchymal disease) was removed. A 2-tailed $p$ value of $<0.05$ was considered significant.

both $(\mathrm{p}<0.0001)$. The median intravitreal IL-8 levels were significantly rise in the study group when compared to control group $1(\mathrm{p}=0.001)$ and control group $2(\mathrm{p}=0.004)$. The median values of the intravitreal IL- 6 were significantly higher in the study group when compared to the control group $1(\mathrm{p}=0.001)$ as shown in Figure 1. The vitreous levels of TNF- $\alpha$, IL-1 $\beta$, IL-17, IL-1Ra and IL-10 revealed no statistical difference between the study group and control groups. The comparison of the vitreous cytokine concentrations revealed no statistical difference between the control groups. There was no statistical difference in serum adipocytokine levels between the study group and the control group 1 ( $\mathrm{p}>0.05)$.

In the study group, the median values of intravitreal IL-17, IL-8 and IL-6 were significantly higher than those of serum levels. Conversly, the median values of circulating IL-10, IL-1Ra were significantly higher than those of vitreous levels (Figure 2).

The correlation analysis of adipocytokines with BMI, FBG, and $\mathrm{HbA} 1 \mathrm{c}$ is presented in Table 3. We did not find significant correlation between circulating and intravitreal adipocytokine levels and BMI, FBG, or HbA1c in the study group.

\section{Discussion}

World Health Organisation defined obesity as abnormal or excessive fat accumulation with a BMI of $30 \mathrm{~kg} / \mathrm{m}^{2}$ or more that presents life-threatening complications such as cardiovascular disease and DM. In our study the mean BMI of diabetic patients was $31 \pm 6 \mathrm{~kg} / \mathrm{m}^{2}$. The percentage of the patients with a BMI of greater than $30 \mathrm{~kg} / \mathrm{m}^{2}$ was $54.5 \%$. Our research is the first study that evaluate the correlation between the adipocytokine concentrations and BMI in PDR. Literature suggests that adipocytokines are

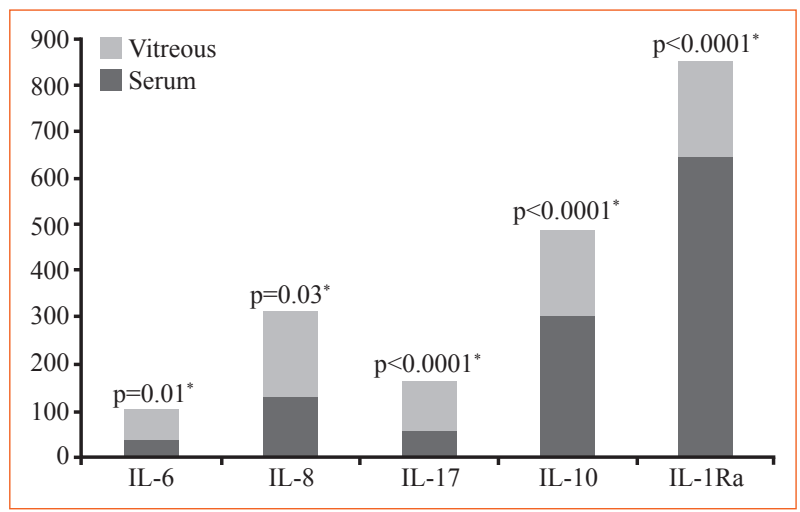

Figure 2. Distribution of the adipocytokine concentrations in the study group. The median intravitreal concentrations of IL-17: 104 pg/mL, IL-8: 180 pg/mL, IL-6: 64.1 pg/mL, IL-10: 184.2 pg/mL, IL-1Ra: $236 \mathrm{pg} / \mathrm{mL}$. The median circulating levels of IL-17: $55 \mathrm{pg} /$ $\mathrm{mL}$, IL-8: $127.2 \mathrm{pg} / \mathrm{mL}$, IL-6: 35 pg/mL, IL-10: $205.3 \mathrm{pg} / \mathrm{mL}$, IL1Ra: $640.8 \mathrm{pg} / \mathrm{mL}$. The median values of IL-17, IL-8 and IL-6 were significantly rise in vitreous when compared to serum. The median levels of IL-10, IL-1Ra were significantly rise in the serum when compared to vitreous. $* \mathrm{p}<0.05$. 
released from subcutaneous adipose tissue in the obese [15]. Other aspect is that the release of cytokines is dependent to BMI [16]. The question is that why BMI did not correlate with adipocytokines in our study? There are three possibilities. First, in our study no one had a BMI of greater than $45 \mathrm{~kg} / \mathrm{m}^{2}$. Fain et al. [17] reported that the IL- 8 release by adipose tissue from individuals with a BMI of $45 \mathrm{~kg} / \mathrm{m}^{2}$ is increased 4-fold compared to individuals with a BMI of $32 \mathrm{~kg} / \mathrm{m}^{2}$. Second, the subcutaneous adipose tissue may not be the only origin of inflammatory markers in diabetic patients. Vettor et al. [6] suggested that the release of VEGF, IL-6, IL-8, IL-10, resistin, TGF $\beta 1$, and PAI-1 from visceral (intra-abdominal) adipose tissue is greater than subcutaneous adipose tissue. Moreover, Dusserre et al. [18] found that the expression of some adipocytokines increased in visceral adipose tissue when compared to subcutaneous abdominal tissue in individuals with a BMI of lower than $30 \mathrm{~kg} / \mathrm{m}^{2}$. Third, in obesity inflammatory markers are released from organs other than adipose tissue, primarily the liver and immune cells as discussed by Trayhurn et al. [19].

Higher amounts of $\mathrm{HbA1c}$, indicating poorer control of blood glucose levels, are associated with cardiovascular disease, nephropathy, and retinopathy. The normal range for $\mathrm{HbAlc}$ is $20-42 \mathrm{mmol} / \mathrm{mol}$ in our laboratory. The study group had a mean $\mathrm{HbAlc}$ of $74 \mathrm{mmol} / \mathrm{mol}$. We did not find significant correlation between adipocytokines and $\mathrm{HbA} 1 \mathrm{c}$. In contrast to our results Ozturk et al. [20] reported the correlation between $\mathrm{HbA} 1 \mathrm{c}$ and circulating IL-10 and MCP-1 in patients with PDR.

FBG is another parameter that denotes good metabolic control. The study group had a mean FBG of $179 \pm 74 \mathrm{mg} / \mathrm{dL}$. No significant correlation was found between adipocytokines and FBG. Mocan et al. [21] determined the correlation between the vitreous levels of IL-6 and FBG, but they did not find significant correlation between the circulating levels of IL-6 and FBG.

Based on our findings, the key adipocytokines that differentiate between the diabetic group and the control groups were intravitreal VEGF, IL-6, and IL-8. IL-6 is an important clinical marker in PDR. It indicates activity of neovascularization [22]. IL-8 is an inflammatory and angiogenic mediator. Increased vitreous leves of IL-6 and IL- 8 correlate with disease severity as discussed by Canataroglu et al. [23]. However, Petrovic et al. [24] stated that increased vitreous levels of IL- 8 is not associated with active PDR. VEGF plays an important role in leukocyte adhesion, which is responsible for early blood-retinal barrier breakdown [5]. Yoshimura et al. [25] have reported the increased levels of vitreal VEGF, IL-6, IL-8 and MCP-1 in PDR. Previous studies also reported increased vitreous levels of VEGF [26,27], IL-6 [21-23,25,27], IL-8 [23-25,28], and MCP-1 [25,26,28] in PDR.

The comparison of serum cytokine levels between the study group and the control group 1 revealed no significant changes. Maier et al. [29] stated that IL-8 and VEGF levels do not differ significantly between the study and control groups. On the other hand, serum levels of VEGF and MCP-1 significantly increased in PDR as demonstrated by Ozturk et al. [20]. In summary, the intravitreal concentrations of some adipocytokines were considerably higher in the study group than control groups, whereas the serum levels did not differ significantly between groups. It seems that local inflammation may be underlying cause of vascular pathology of PDR. There are some possibilities about the source of the high levels of inflammatory and proangiogenic cytokines within the vitreous. The first one is that the breakdown of the bloodretina barrier. Joussen et al. [30] hypothesized that the elevated serum levels of inflammatory cytokines are elevated in the vitreous fluid by the breakdown of the bloodretina barrier. The second possibility is that cells like macrophages, monocytes, retinal pigment epithelial cells, and glial cells are the main factors accounting for the high levels of cytokines $[31,32]$. Once the blood-retina barrier is destroyed the elevated levels of these inflammatory cytokines lead chemotaxis of leukocytes and expression of other inflammatory and proangiogenic mediators into the vitreous [31].

There is, however, another possibility. It is accepted that physiological angiogenesis is a result of a net balance between the activities exerted by positive and negative regulators [4]. We demonstrated that intravitreal IL-6, IL-8, and IL-17 concentrations, pro-inflammatory mediators, were significantly higher than those of serum levels, whereas the intravitreal IL-10 and IL-1Ra levels, antiinflammatory mediators, were found to be significantly decreased in diabetic patients. The equilibrium between the pro- and anti- inflammatory mediators was disturbed in favor of proinflammatory and proangiogenic cytokines in the vitreous humour in PDR. Hernández et al. found that IL-10 levels are lower in the serum of diabetic patients than the control subjects. They also found no significant elevation of intravitreal IL-10 in the diabetic group [28]. IL-10 can repress proinflammatory responses and limit unnecessary tissue disruptions caused by inflammation [16]. IL-1Ra is the physiological antagonist of IL$1 \beta$. Levels of IL-1Ra and IL-10 are elevated in obesity [16]. However in our study the augmentation of the proinflammatory cytokines was not counterposed by an increase of IL-10 and IL-1Ra. In our opinion, the feedback mechanism among the inflammatory cytokines within the vitreous may be disturbed in PDR.

Since the control group 1 was not composed of healthy subjects, we evaluated vitreous specimens of cadavers. We collected vitreous specimens within 6 hours after death. Post-mortem vitreous is rarely analyzed in clinical practice. Canataroglu et al. [23] obtained vitreous fluid specimens within 4 hours, Limb et al. [33] collected vitre- 
ous fluids within 6 to 18 hours after death. No standardized methods have been validated. Boulagnon et al. [34] reported that the composition of vitreous is more stable and less affected by post-mortem changes than cerebrospinal fluid or blood. Also, in the early post-mortem period, vitreous humour has the same appearance as in vivo [34]. Thus, we analyzed the levels of cytokines in the early post-mortem vitreous specimens.

Multiplex bead analysis offers simultaneous quantification of cytokines, growth factors, chemokines, neurotrophic factors, and neuropeptides, either singly, or in multiplexed assays in serum [20], plasma [35], synovial fluid [36], peripheral blood mononuclear cell supernatants [37], vitreous fluid [26], and tear [38] with limited sample volume. Maier et al. [29] suggested that multiplex bead analysis and Enzyme-Linked Immunosorbent Assay (ELISA) are highly correlated for measurement of cytokines in serum and vitreous and this technology is more rapid and cost effective than ELISA. In future with this technology, diabetic patients could be subcategorized by their cytokine pattern such as patients with vitreous hemorrhage, retinal detachment, neovascular glaucoma, or macular edema. They could be treated by combined therapies targeting inflammatory cytokines. The efficacy of ongoing therapy could be assessed by using this technology.

Inconclusion, inPDR intravitreallevels of proinflammatory adipocytokines increase in the vitreous humour since the feedback inhibitors do not. In PDR VEGF, IL-6 and IL-8 are the key cytokines in the immunologic mechanism of vascular pathology. PDR is a chronic subclinical local inflammatory disease. Subcutaneous adipose tissue, abdominal obesity, may not be the primary origin of the inflammatory and proangiogenic cytokines in PDR.

\section{Ethical issues}

This study was approved by the Ethics Committee for Clinical Studies of Hacettepe University, Faculty of Medicine (16.04.2009 TBK 09/11-37).

\section{Acknowledgement}

This research was supported by Hacettepe University Science Foundation Grant 4816. This study was presented as a residency thesis, 2010, in Hacettepe University, Opthalmology Department.

Part of this research was presented at the $11^{\text {th }}$ Euretina Congress, 2011, London as poster.

This study was presented in $45^{\text {th }}$ National Congress of Opthalmology of the Turkish Opthalmology Society (TOD), 2011, Turkish Republic of Northern Cyprus as an oral presentation.

\section{Conflict of Interest}

There are no conflicts of interest among the authors.

\section{References}

[1] Arjamaa O, Nikinmaa M. Oxygen-dependent diseases in the retina: role of hypoxia-inducible factors. Exp Eye Res 2006; 83(3):473-83.

[2] Adamis AP, Berman AJ. Immunological mechanisms in the pathogenesis of diabetic retinopathy. Semin Immunopathol 2008; 30(2):65-84.

[3] Adamis AP. Is diabetic retinopathy an inflammatory disease? Br J Ophthalmol 2002; 86(4):363-5.

[4] Naldini A, Carraro F. Role of inflammatory mediators in angiogenesis. Curr Drug Targets Inflamm Allergy 2005; 4(1):3-8.

[5] Joussen AM, Poulaki V, Qin W, Kirchhof B, Mitsiades N, et al. Retinal vascular endothelial growth factor induces intercellular adhesion molecule- 1 and endothelial nitric oxide synthase expression and initiates early diabetic retinal leukocyte adhesion in vivo. Am J Pathol 2002; 160(2):501-9.

[6] Vettor R, Milan G, Rossato M, Federspil G. Review article: adipocytokines and insulin resistance. Aliment Pharmacol Ther 2005; 22 Suppl 2:3-10.

[7] Rose DP, Komninou D, Stephenson GD. Obesity, adipocytokines, and insulin resistance in breast cancer. Obes Rev 2004; 5(3):15365.

[8] Vona-Davis L, Rose DP. Adipokines as endocrine, paracrine, and autocrine factors in breast cancer risk and progression. Endocr Relat Cancer 2007; 14(2):189-206.

[9] Kaur T, Zhang ZF. Obesity, breast cancer and the role of adipocytokines. Asian Pac J Cancer Prev 2005; 6(4):547-52.

[10] Housa D, Housová J, Vernerová Z, Haluzík M. Adipocytokines and cancer. Physiol Res 2006; 55(3):233-44.

[11] Hou WK, Xu YX, Yu T, Zhang L, Zhang WW, et al. Adipocytokines and breast cancer risk. Chin Med J 2007; 120(18):1592-6.

[12] Matsuzawa Y. Adipocytokines and metabolic syndrome. Semin Vasc Med 2005; 5(1):34-9.

[13] Ruan H, Lodish HF. Regulation of insulin sensitivity by adipose tissue-derived hormones and inflammatory cytokines. Curr Opin Lipidol 2004; 15(3):297-302.

[14] Life Technologies http://www.lifetechnologies.com/order/catalog/product/LHC6003 (Last accessed: June 2013).

[15] Haque WA, Garg A. Adipocyte biology and adipocytokines. Clin Lab Med 2004; 24(1): 217-34.

[16] Fain JN. Release of interleukines and other inflammatory cytokines by human adipose tissue is enhanced in obesity and primarly due to the nonfat cells. Vitam Horm 2006; 74:443-77.

[17] Fain JN, Madan AK, Hiler ML, Cheema P, Bahouth SW. Comparison of the release of adipokines by adipose tissue, adipose tissue matrix, and adipocytes from visceral and subcutaneous abdominal adipose tissues of obese humans. Endocrinology 2004; 145(5):2273-82.

[18] Dusserre E, Moulin P, Vidal H. Differences in mRNA expression of the proteins secreted by the adipocytes in human subcutaneous and visceral adipose tissues. Biochim Biophys Acta 2000; 1500(1):88-96.

[19] Trayhurn P, Wood IS. Adipokines: inflammation and the pleiotropic role of white adipose tissue. Br J Nutr 2004; 92(3):347-55.

[20] Ozturk BT, Bozkurt B, Kerimoglu H, Okka M, Kamis U, et al. Effect of serum cytokines and VEGF levels on diabetic retinopathy and macular thickness. Mol Vis 2009; 15:1906-14.

[21] Mocan MC, Kadayifcilar S, Eldem B. Elevated intravitreal interleukin-6 levels in patients with proliferative diabetic retinopathy. Can J Ophthalmol 2006; 41(6):747-52.

[22] Arjamaa O, Pöllönen M, Kinnunen K, Ryhänen T, Kaarniranta

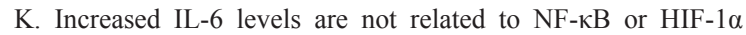


transcription factors activity in the vitreous of proliferative diabetic retinopathy J Diabetes Complications 2011; 25(6):393-7.

[23] Canataroglu H, Varinli I, Ozcan AA, Canataroglu A, Doran F, et al. Interleukin (IL)-6, interleukin (IL)-8 levels and cellular composition of the vitreous humor in proliferative diabetic retinopathy, proliferative vitreoretinopathy, and traumatic proliferative vitreoretinopathy. Ocul Immunol Inflamm 2005; 13(5):375-81

[24] Petrovic MG, Korosec P, Kosnik M, Hawlina M. Vitreous levels of interleukin- 8 in patients with proliferative diabetic retinopathy. Am J Ophthalmol 2007; 143(1):175-6.

[25] Yoshimura T, Sonoda KH, Sugahara M, Mochizuki Y, Enaida H, et al. Comprehensive analysis of inflammatory immune mediators in vitreoretinal diseases. PLoS One 2009; 4(12):8158.

[26] Maier R, Weger M, Haller-Schober EM, El-Shabrawi Y, Wedrich A, et al. Multiplex bead analysis of vitreous and serum concentrations of inflammatory and proangiogenic factors in diabetic patients. Mol Vis 2008; 14:637-43.

[27] Banerjee S, Savant V, Scott RA, Curnow SJ, Wallace GR, et al. Multiplex bead analysis of vitreous humor of patients with vitreoretinal disorders. Invest Ophthalmol Vis Sci 2007; 48(5):2203-7.

[28] Hernández C, Segura RM, Fonollosa A, Carrasco E, Francisco $\mathrm{G}$, et al. Interleukin-8, monocyte chemoattractant protein-1 and IL-10 in the vitreous fluid of patients with proliferative diabetic retinopathy. Diabet Med 2005; 22(6):719-22.

[29] Maier R, Weger M, Haller-Schober EM, El-Shabrawi Y, Theisl A, et al. Application of multiplex cytometric bead array technology for the measurement of angiogenic factors in the vitreous. Mol Vis 2006; 12:1143-7.

[30] Joussen AM, Poulaki V, Le ML, Koizumi K, Esser C, et al. A central role for inflammation in the pathogenesis of diabetic retinopathy. FASEB J 2004; 18(12):1450-2.

[31] Ishida S, Yamashiro K, Usui T, Kaji Y, Ogura Y, et al. Leukocytes mediate retinal vascular remodeling during development and vaso-obliteration in disease. Nat Med 2003; 9(6):781-8.

[32] Kern TS. Contributions of inflammatory processes to the development of the early stages of diabetic retinopathy. Exp Diabetes Res 2007; 2007:95103.

[33] Limb GA, Hickman-Casey J, Hollifield RD, Chignell AH. Vascular adhesion molecules in vitreous from eyes with proliferative diabetic retinopathy. Invest Ophthalmol Vis Sci 1999; 40(10):2453-7.

[34] Boulagnon C, Garnotel R, Fornes P, Gillery P. Post-mortem biochemistry of vitreous humor and glucose metabolism: an update. Clin Chem Lab Med 2011; 49(8):1265-70.

[35] Szodoray P, Alex P, Brun JG, Centola M, Jonsson R. Circulating cytokines in primary Sjögren's syndrome determined by a multiplex cytokine array system. Scand J Immunol 2004; 59(6):592-9.

[36] Raza K, Falciani F, Curnow SJ, Ross EJ, Lee CY, et al. Early rheumatoid arthritis is characterized by a distinct and transient synovial fluid cytokine profile of $\mathrm{T}$ cell and stromal cell origin. Arthritis Res Ther 2005; 7(4):784-95.

[37] Kinter AL, Hennessey M, Bell A, Kern S, Lin Y, et al. CD25(+) $\mathrm{CD} 4(+)$ regulatory $\mathrm{T}$ cells from the peripheral blood of asymptomatic HIV-infected individuals regulate $\mathrm{CD} 4(+)$ and $\mathrm{CD} 8(+)$ HIV-specific $\mathrm{T}$ cell immune responses in vitro and are associated with favorable clinical markers of disease status. J Exp Med 2004; 200(3):331-43.

[38] Topcu Yilmaz P, Atakan N, Bozkurt B, Irkec M, Aban D, et al. Determination of tear and serum inflammatory cytokines in patients with rosacea using multiplex bead technology. Ocul Immunol Inflamm 2013; 21(5):351-9. 